\title{
EXAMINING THE VARIATION BETWEEN THE CONVENTIONAL AND CONTEMPORARY VALUATION OF RESIDENTIAL INVESTMENT PROPERTIES IN LAGOS
}

\author{
Stanley Chika Nwaogu' ${ }^{1}$, Ifeanyichukwu Valentine Nwafor ${ }^{1}$ \\ and Raphael Oshiobugie Sado ${ }^{2}$ \\ ${ }^{1}$ Department of Estate Management, University of Nigeria, Enugu Campus, Enugu, Nigeria. \\ ${ }^{2}$ Department of Estate Management, Nnamdi Azikiwe University, Awka.
}

Cite this article:

Nwaogu S.C., Nwafor I.V., Sado R.O. (2022), Examining the Variation Between the Conventional and

Contemporary Valuation of Residential Investment Properties in Lagos. African Journal of Accounting and Financial Research 5(1), 4558. DOI: $10.52589 / A J A F R-$ W0KF5Z7O

\section{Manuscript History}

Received: 22 Jan 2022

Accepted: 13 Feb 2022

Published: 26 Feb 2022

Copyright $\odot 2022$ The Author(s). This is an Open Access article distributed under the terms of Creative Commons AttributionNonCommercial-NoDerivatives 4.0 International (CC BY-NC-ND 4.0 ), which permits anyone to share, use, reproduce and redistribute in any medium, provided the original author and source are credited.
ABSTRACT: Due to the interplay between the forces of demand and supply in the determination of residential property investment valuation, there is continuous increase in rental value and rent review pattern and as such, conventional valuation of residential property investment has become inappropriate as it cannot handle the problems of rental values, rental growth, impact of inflation and rent review pattern experienced in the Nigerian property market. The objectives were to determine the annual rental growth rate pattern for residential properties from 2014-2020 and ascertain the level of variation in the use of conventional and contemporary investment methods in determining the value of such real estate assets in Lagos State, Nigeria. Appropriate descriptive approach was adopted and the result showed that rental values increased within the period, rental growth followed a similar trend, rent review pattern was mostly three years, and practitioners were aware of discounted cash flow. Valuation results revealed $6.67 \%$ variation for discounted cash flow, $0 \%$ for real value model and $25 \%$ rational approach. The use of a constant income annuity in perpetuity for conventional investment method of valuation as a single income stream would result in erroneous valuation as conventional technique relies fully on comparable evidence. The contemporary techniques on the other hand integrate property as part of the larger investment community which enables estate valuers to make qualitative market valuation where there is no comparable evidence. This study therefore recommends that contemporary valuation techniques are appropriate in the market valuation of residential property investments, particularly in the market valuation of reversionary freehold.

KEYWORDS: Residential Property Investment, Rental Growth, Property Investment Valuation, Capitalization Rate, Rent Review Pattern. 


\section{INTRODUCTION}

Before the introduction of inflation in the residential property investment valuation worldwide, residential property investment valuation was strictly predicated on the principle of conventional technique, which relies on assumptions of no growth in future rental value over present rental value and rent fixed on a long term basis without rent review. The applicability of contemporary valuation techniques to the conventional valuation of residential property investments in Nigeria has been explored considering model building techniques. Contemporary valuation has been suggested for property investment valuation within the context of the Nigerian property market system due to continuous increase in rental values of residential property investments in Lagos, which has raised concern on the dynamics operating in the rental growth of residential property investments in the city. It is not certain whether the timing and size of this growth is rational in every case. In the light of the facts surrounding the unsubstantiated observations, it is imperative to ascertain the level of variation between the conventional and contemporary methods of residential property investment valuation in Lagos.

The study therefore looked at annual rental growth rate pattern for residential properties from 2014 to 2020 and the level of variation in the use of conventional and contemporary investment method in the market valuation of residential property investments in Lagos

\section{LITERATURE REVIEW}

Valuation techniques adopted in most residential investment properties do not reflect the true nature of the property market due to rent increase, rental growth, impact of inflation and inappropriate rent review pattern which over time creates variations in the use of conventional and contemporary valuation techniques in the Nigerian property market (Udo, 2018). Property investment valuation is simply the estimation of future benefits to be enjoyed by the owner of a freehold or leasehold interest in land or property, which expresses those future benefits in their present worth. These exercises entail mathematical models that require proper consideration of variables before figures are substituted in a proven mathematical formula which shows the real life scenario of the facts under consideration (Sykes, 2019).

This exercise involves the use of mathematical models (Udo, 2018) and coincides with the view of Baum (2017) that property investment valuation as a process requires careful consideration of a number of variables before figures can be substituted in a mathematically proven formula. The formula or model used represents real-life situations. Property investment valuation basically requires the estimation of two major parameters. These parameters are the rental value and the capitalisation rate applied to the current and projected cash flows.

The parameters to residential property investment valuation are rental values of residential properties and rate of capitalization to current and projected cash flows before the introduction of inflation in the property market, that is, during the pre-reverse yield gap. Investment property valuation was strictly based on the logic of the conventional technique that depends on the assumptions that there are no future rental value growth over present rental value, which shows that rents are fixed on long term bases without rent review, and rate of capitalisation adopted in residential investment valuation is the internal rate of return expected from investment (Sykes, 2018). 
Ajayi (2019) opined that the parameters of residential investment valuations are the rental value and the capitalisation rate applied to the current and projected cash flows. Prior to the advent of inflation in the property market - that is, during the pre-reverse yield gap - property investment valuation was solely based on the logic of the conventional technique which relies on some assumptions that there is no growth in future rental value over present rental value, that rents are fixed on long leases without review, and that the capitalisation rate used in the valuation is the internal rate of return expected from the investment. Furthermore, the reverse yield gap, which is the yield gap that existed between property and gilt yields before inflation, became a serious consideration in the valuation of residential investment due to the rise in property yields over gilt yields. Dugeri (2019) analysed property and gilt yields and the yield gap that existed between them for the period 1960-1969. From the analysis, it was discovered that for the period 1960-1963, gilt yields were higher than property yields with a positive yield gap and by 1964, the yield gap had reversed due to the rise in property yields over gilt yields. This rise did not imply that property was less risky than gilt, but merely confirmed the presence of inflation in the property market. However, the development was due to the increase in property rental values as evidenced by the introduction of rent reviews, leading to severe disturbance to the assumptions that formed the logic of the conventional technique. This development fundamentally changed the applicability of the conventional valuation model as the model lacked the facility to handle rent reviews and rental growth, resulting in the inadequacy of the model for the valuation of residential property investments in times of inflation and as such, there is need to ascertain the level of variation between the conventional and contemporary valuation of residential investment properties in Nigeria.

\section{METHODOLOGY}

The study adopted qualitative and quantitative techniques. In order to achieve the expected result, the study sampled 200 valuation reports from practicing Estate Surveyors and Valuers in Lagos, while 168 were used as sample size.

The rental growth, average rental growth rate and coefficient of variation for residential property investments in Lagos for the period, 2014-2020 were determined using geometric mean rental growth rate and is determined as follows:

$$
X=\sqrt[n]{X_{1} x X_{2} x X_{3} x} \ldots x X_{n}
$$

where $\mathrm{x}$ represents geometric mean and $\mathrm{x}_{1}, \mathrm{x}_{2}, \ldots \mathrm{x}_{\mathrm{n}}$ represents rental growth rate for each year and $\mathrm{n}=$ the total number of years within the period under study.

The standard deviation is given by:

The standard deviation of rental growth rates to the average rental growth rate were derived using $=\sqrt{\sum \quad\left(\frac{x-x}{N-1}\right)^{2}}$, while the coefficient of variation being the ratio of standard deviation of rental growth rates to the average rental growth rate was gotten using:

Coefficient of variation $=\underline{\text { Standard Deviation of Rental Growth Rate }}$

Average Rental Growth Rate 


\section{RESULTS AND DISCUSSION}

In this section, an analysis of the valuation reports collected were presented in the following tables:

Table 1: Collection of Valuation Report from Estate Surveyors and Valuers

\begin{tabular}{|l|l|l|l|l|l|l|}
\hline $\begin{array}{l}\text { Class of } \\
\text { respondent }\end{array}$ & $\begin{array}{l}\text { Number of } \\
\text { valuation } \\
\text { report } \\
\text { collected }\end{array}$ & $\begin{array}{l}\text { Number of } \\
\text { valuation } \\
\text { report } \\
\text { considered }\end{array}$ & $\begin{array}{l}\text { Number of } \\
\text { valuation } \\
\text { report not } \\
\text { considered }\end{array}$ & $\begin{array}{l}\text { Percentage of } \\
\text { total number } \\
\text { of report } \\
\text { considered }\end{array}$ & $\begin{array}{l}\text { Percentage } \\
\text { of valuation } \\
\text { report not } \\
\text { considered }\end{array}$ & Total \\
\hline $\begin{array}{l}\text { Practicing } \\
\text { estate } \\
\text { surveyors } \\
\text { and valuers }\end{array}$ & 200 & 168 & 32 & $84 \%$ & $16 \%$ & $100 \%$ \\
\hline Total & 200 & 168 & 32 & $84 \%$ & $16 \%$ & $100 \%$ \\
\hline
\end{tabular}

As depicted from Table 1, 200 valuation reports were collected from estate surveying and valuation firms. Out of this number, 168 reports were considered relevant, representing $84 \%$ of the total reports collected while 32 reports representing $16 \%$ were not considered.

Table 2: Number of Residential Properties Valued

\begin{tabular}{|l|l|l|}
\hline Description & Frequency & Percentage \\
\hline 2-Bedroom Flat & 75 & $44.6 \%$ \\
\hline 3-Bedroom Flat & 93 & $55.4 \%$ \\
\hline Total & 168 & 100 \\
\hline
\end{tabular}

Table 2 showed that $60 \%$ of the residential units considered are 2-bedroom flats while $40 \%$ are 3-bedroom flats.

Table 3: Weighted Mean Rents for 2-Bedroom Flats in the Study Area, 2014-2020

\begin{tabular}{|l|l|l|l|l|}
\hline Year & Rent $(\mathrm{N})$ & Frequency & Relative Frequency & Weighted Rent \\
\hline 2014 & $\mathrm{~N} 2,300,000$ & 24 & 0.143 & $\mathrm{~N} 328,900$ \\
\hline 2015 & $\mathrm{~N} 2,700,000$ & 24 & 0.143 & $\mathrm{~N} 386,100$ \\
\hline 2016 & $\mathrm{~N} 2,700,000$ & 24 & 0.143 & $\mathrm{~N} 386,100$ \\
\hline 2017 & $\mathrm{~N} 2,700,000$ & 24 & 0.143 & $\mathrm{~N} 386,100$ \\
\hline 2018 & $\mathrm{~N} 3,000,000$ & 24 & 0.143 & $\mathrm{~N} 429,000$ \\
\hline 2019 & $\mathrm{~N} 3,000,000$ & 24 & 0.143 & $\mathrm{~N} 429,000$ \\
\hline 2020 & $\mathrm{~N} 3,000,000$ & 24 & 0.143 & $\mathrm{~N} 429,000$ \\
\hline & $\sum$ & 168 & 1.00 & $\mathrm{~N} 2,774,200$ \\
\hline
\end{tabular}

The same procedure was adopted for the calculation of weighted rents for 3-bedroom flats as summarised in Table 4. 
Table 4: Weighted Mean Rents for 3-Bedroom Flats in the Study Area, 2014-2020

\begin{tabular}{|l|l|l|l|l|}
\hline Year & Rent $(\mathrm{N})$ & Frequency & Relative Frequency & Weighted Rent \\
\hline 2014 & $\mathrm{~N} 2,700,000$ & 24 & 0.143 & $\mathrm{~N} 386,100$ \\
\hline 2015 & $\mathrm{~N} 3,200,000$ & 24 & 0.143 & $\mathrm{~N} 457,600$ \\
\hline 2016 & $\mathrm{~N} 3,200,000$ & 24 & 0.143 & $\mathrm{~N} 457,600$ \\
\hline 2017 & $\mathrm{~N} 3,200,000$ & 24 & 0.143 & $\mathrm{~N} 457,600$ \\
\hline 2018 & $\mathrm{~N} 3,500,000$ & 24 & 0.143 & $\mathrm{~N} 500,500$ \\
\hline 2019 & $\mathrm{~N} 3,500,000$ & 24 & 0.143 & $\mathrm{~N} 500,500$ \\
\hline 2020 & $\mathrm{~N} 3,500,000$ & 24 & 0.143 & $\mathrm{~N} 500,500$ \\
\hline & $\sum$ & 168 & 1.00 & $\mathrm{~N} 3,260,400$ \\
\hline
\end{tabular}

Rental growth for 2-bedroom flats and 3-bedroom flats in the study area, 2014-2020.

The annual rental growth rates were obtained from the properties under study for the period, 2014-2020. The annual rental growth rates were obtained from the weighted rents in each type of property for each year under study. The annual rental growth rates were calculated as a percentage increase in rent for each of the years under study. For example, the annual rental growth rate in 2-bedroom flats for 2014 is $17.39 \%$. This is calculated as follows:

Rent for 2014

Rent for 2015

Rental Increase

Rental growth rate for 2009

$$
\text { N 2,300,000 }
$$

$$
\text { N 2,700,000 }
$$

$$
\text { N 400,000 }
$$

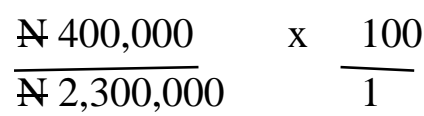

\begin{tabular}{|c|c|c|c|}
\hline Rent for 2014 & $2,700,000$ & & \\
\hline Rent for 2015 & N $3,200,000$ & & \\
\hline Rental Increase & N 500,000 & & \\
\hline Rental growth rate for 2009 & N 500,000 & $\mathrm{x}$ & 100 \\
\hline & 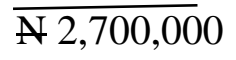 & & 1 \\
\hline
\end{tabular}$$
=17.39 \%
$$

Also, the annual rental growth rate in 3-bedroom flats for 2014 is $18.52 \%$. This is calculated as follows: 
African Journal of Accounting and Financial Research

ISSN: $2682-6690$

Volume 5, Issue 1, 2022 (pp. 45-58)

www.abjournals.org

Table 5: Annual Rental Growth for 2-Bedroom Flats and 3 Bedroom Flats in the Study Area, 2014-2020.

\begin{tabular}{|l|l|l|}
\hline \multirow{2}{*}{ Year } & \multicolumn{2}{|c|}{ Annual Growth Rate } \\
\cline { 2 - 3 } & 2 -Bedroom Flat (\%) & 3 -Bedroom Flat (\%) \\
\hline 2014 & - & - \\
\hline 2015 & 17.39 & 18.52 \\
\hline 2016 & - & - \\
\hline 2017 & - & - \\
\hline 2018 & 11.11 & 9.38 \\
\hline 2019 & - & - \\
\hline 2020 & - & - \\
\hline
\end{tabular}

Table 6: Average Rental Growth Rates for 2-Bedroom Flats in the Study Area

\begin{tabular}{|l|l|l|l|}
\hline YEAR & $\mathrm{X}$ & $(\mathrm{x}-\overline{\mathrm{x}})$ & $(\mathrm{x}-\overline{\mathrm{x}})^{2}$ \\
\hline 2014 & - & -4.07 & 16.5649 \\
\hline 2015 & 17.39 & 13.32 & 177.4224 \\
\hline 2016 & - & -4.07 & 16.5649 \\
\hline 2017 & - & -4.07 & 16.5649 \\
\hline 2018 & 11.11 & 7.04 & 49.5616 \\
\hline 2019 & - & -4.07 & 16.5649 \\
\hline 2020 & - & -4.07 & 16.5649 \\
\hline$\sum$ & 28.5 & & 309.8085 \\
\hline
\end{tabular}

Average Growth Rate (X)

$=\sqrt[7]{(1.0)(1.1739)(1.0)(1.0)(1.1111)(1.0)(1.0)}-1$

$=\sqrt[7]{(1.3043)}$

$=1.0387-1$

$=0.0387$

$=3.87 \%$

Standard Deviation $=\sqrt{\frac{309.8085}{6}}$

Standard Deviation $=\sqrt{51.6348}$

$$
=7.19 \%
$$

Coefficient of variation $=\frac{7.19}{4.07}$

$$
=1.7666
$$


Table 7: Average Rental Growth Rates for 3-Bedroom Flats in the Study Area

\begin{tabular}{|l|l|l|l|}
\hline Year & $\mathrm{X}$ & $(\mathrm{x}-\overline{\mathrm{x}})$ & $(\mathrm{x}-\overline{\mathrm{x}})^{2}$ \\
\hline 2014 & - & -3.99 & 15.9201 \\
\hline 2015 & 18.52 & 14.53 & 211.1209 \\
\hline 2016 & - & -3.99 & 15.9201 \\
\hline 2017 & - & -3.99 & 15.9201 \\
\hline 2018 & 9.38 & 5.39 & 29.0521 \\
\hline 2019 & - & -3.99 & 15.9201 \\
\hline 2020 & - & -3.99 & 15.9201 \\
\hline$\sum$ & 27.9 & & 319.7735 \\
\hline
\end{tabular}

Average Growth Rate (X)

$$
\begin{aligned}
& =\sqrt[7]{(1.0)(1.1453)(1.0)(1.0)(1.0938)(1.0)(1.0)}-1 \\
& =\sqrt[7]{(1.2527)} \\
& =1.1193-1 \\
& =0.1193 \\
& =11.93 \%
\end{aligned}
$$

Standard Deviation $=\sqrt{\frac{319.7735}{6}}$

Standard Deviation $=\sqrt{53.2956}$

$$
=7.30 \%
$$

Coefficient of variation $=\frac{7.30}{3.99}$

$$
=1.8296
$$

Table 8: Average Rental Growth Rates, Standard Deviation and Coefficient of Variation for 2-Bedroom Flats and 3-Bedroom Flats in the Study Area, 2009-2018

\begin{tabular}{|l|l|l|l|}
\hline $\begin{array}{l}\text { Type of Residential } \\
\text { Property }\end{array}$ & $\begin{array}{l}\text { Rental Growth Rate, } \\
\text { 2009-2018 }\end{array}$ & Standard Deviation & $\begin{array}{l}\text { Coefficient of } \\
\text { Variation }\end{array}$ \\
\hline 2-Bedroom Flat & 11.11 & 7.19 & 1.7666 \\
\hline 3-Bedroom fFlatlat & 9.38 & 7.30 & 1.8296 \\
\hline
\end{tabular}

Generally, the average rental growth rate for residential properties in the study area for the period, 2014-2020 is phenomenal as summarised in Table 8. The table shows a similar trend for all the residential properties in study. The 3-bedroom flats have the higher rental growth 
African Journal of Accounting and Financial Research

ISSN: $2682-6690$

Volume 5, Issue 1, 2022 (pp. 45-58)

www.abjournals.org

rate followed by 2-Bedroom flats. This proves that investors are likely to get high returns if they invest in such properties.

Table 9: Ranking Lease Structure Often Used for Residential Properties in the Study Area

\begin{tabular}{|l|l|l|l|l|l|l|l|l|}
\hline Rank & Always & Sometimes & Seldom & $\begin{array}{l}\text { Not } \\
\text { Used }\end{array}$ & N & FX & $\overline{\mathbf{x}}$ & Ranking \\
\hline & $\mathrm{X}$ & $\mathrm{X}$ & $\mathrm{X}$ & $\mathrm{X}$ & & & & \\
\hline Weekly & 0 & 0 & 18 & 150 & 168 & 186 & 1.11 & 2 \\
\hline Monthly & 95 & 73 & 0 & 0 & 168 & 599 & 3.57 & 4 \\
\hline $\begin{array}{l}\text { Biannual (Half } \\
\text { Yearly) }\end{array}$ & 0 & 136 & 24 & 8 & 168 & 464 & 2.76 & 3 \\
\hline Annually (Yearly) & 153 & 15 & 0 & 0 & 168 & 657 & 3.91 & 5 \\
\hline $\begin{array}{l}\text { Biennial (Every } \\
\text { Two Years) }\end{array}$ & 0 & 0 & 12 & 156 & 168 & 180 & 1.07 & 1 \\
\hline Total & & & & & & & 2.48 & \\
\hline
\end{tabular}

Table 9 showed the mean mark calculated from the response of the respondents on ranking lease structure often used for residential properties. Annually (yearly) was rated highest with a weighted mean score of 3.91 while biennial (every two years) on the other hand was the least rated from the valuation report used for the study, having a weighted mean score of 1.07. This result confirms that annually (yearly) is the major lease structure used for residential properties in the study area.

Table 10: Rent Review Intervals Observed in Residential Properties in Lagos

\begin{tabular}{|l|l|l|l|l|l|l|}
\hline Description & \multicolumn{6}{l}{$\begin{array}{l}\text { Rent Review Intervals Observed and Frequency of } \\
\text { Properties }\end{array}$} \\
\cline { 2 - 8 } & 2 years & 3 years & 4 years & 5 years & 6 years & Total \\
\hline 2-Bedroom Flat & 36 & 28 & 11 & - & - & 75 \\
\hline 3-Bedroom Flat & 48 & 35 & 10 & - & - & 93 \\
\hline Total & 84 & 63 & 21 & - & - & 168 \\
\hline
\end{tabular}

\section{Expected Rent Review Pattern in Residential Property Investments in Lagos}

Data collected on rent review frequency in residential properties in Lagos, as presented in Table 11 , reveals that most rent reviews in residential properties in the city are between 2 and 3 years, representing about $87.5 \%$ of the intervals observed. The expected rent review pattern is 2.625 (say 3 years). The analysis for expected rent review pattern is presented in Table 11 as follows: 
Table 11: Expected Rent Review Pattern in Residential Property Investments in Lagos

\begin{tabular}{|l|l|l|l|l|}
\hline $\begin{array}{l}\text { Rent Review } \\
\text { Pattern }\end{array}$ & Frequency & \% Occurrence & Probability & $\begin{array}{l}\text { Expected Rent Review } \\
\text { Pattern }\end{array}$ \\
\hline 2 years & 84 & 50 & 0.5 & 1 \\
\hline 3 years & 63 & 37.5 & 0.375 & 1.125 \\
\hline 4 years & 21 & 12.5 & 0.125 & 0.5 \\
\hline 5 years & - & - & - & - \\
\hline 6 years & - & - & - & - \\
\hline Total & 168 & 100 & 1.0000 & 2.625 \\
\hline
\end{tabular}

Table 12: Inflation in Nigeria, 2014-2020

\begin{tabular}{|l|l|}
\hline Year & Inflation $\%$ \\
\hline 2014 & $8.06 \%$ \\
\hline 2015 & $9.01 \%$ \\
\hline 2016 & $15.68 \%$ \\
\hline 2017 & $16.52 \%$ \\
\hline 2018 & $12.09 \%$ \\
\hline 2019 & $11.4 \%$ \\
\hline 2020 & $13.25 \%$ \\
\hline
\end{tabular}

Source: Central Bank of Nigeria (CBN) Annual Reports, 2009-2018

Information on inflation rates were obtained from the annual reports of the Apex Bank for the period 2014-2020 to ascertain the relationship between inflation and annual rental growth in the properties under study, as presented in Table 12.

Table 13: Awareness of the Various Contemporary Investment Methods

\begin{tabular}{|l|l|l|l|l|l|l|}
\hline Description & \multicolumn{2}{|l|}{ Frequency } & Ranking & Ranking & d & $\mathrm{d}^{2}$ \\
\cline { 2 - 7 } & Yes & No & Yes & No & & \\
\hline $\begin{array}{l}\text { Discounted cash flow model } \\
\text { (DCF) }\end{array}$ & 90 & 78 & 1 & 3 & 2 & 4 \\
\hline $\begin{array}{l}\text { Real value/equated yield hybrid } \\
\text { model }\end{array}$ & 85 & 83 & 2 & 2 & 0 & 0 \\
\hline Rational value model & 82 & 86 & 3 & 1 & 2 & 4 \\
\hline & & & & & & 8 \\
\hline
\end{tabular}

The finding in the presentation above showed the summary of the position of estate surveyors and valuers on their awareness of the various contemporary investment methods. It was reviewed that practitioners are aware of the investment methods, that is, the discounted cash. 
African Journal of Accounting and Financial Research

ISSN: 2682-6690

Volume 5, Issue 1, 2022 (pp. 45-58)

\section{Valuation for 2-Bedroom}

Conventional Technique

Rent received

N3,000,000 per annum

YP in Perpetuity @ 5\%

x $\underline{20.0000}$

Capital Value

$\underline{\mathrm{N} 60,000,000}$

Contemporary Technique

At the time of this study, redemption yield on government bonds was about $13.5 \%$ (CBN, 2020) and so a natural conclusion is for equated yield of property to be $15.5 \%$.

$\begin{array}{rll}\text { Estimated Rental Value }(\mathrm{ERV}) \text { for } 2 \text { Bedroom } & = & \mathrm{N} 3,000,000 \text { per annum } \\ \text { Unexpired term } & = & 7 \text { years } \\ \text { Equated Yield }(\mathrm{e}) & = & 15.5 \% \\ \text { Implied Rental growth }(\mathrm{g}) & = & 28.5 \% \text { per annum } \\ \text { Rent Review Period }(\mathrm{t}) & = & 3 \text { years } \\ \text { Inflation Rate }(\mathrm{i}) & = & 13.25 \% \\ \text { Initial Yield }(\mathrm{k}) & = & 5 \%\end{array}$

Appendix 14: Valuation of Freehold Interest Using the Explicit Discounted Cash Flow Technique

\begin{tabular}{|l|l|l|l|c|c|l|}
\hline \multicolumn{1}{|c|}{ Year } & $\begin{array}{c}\text { Current ERV } \\
\text { Per Annum }\end{array}$ & $\begin{array}{c}\text { Amount } \\
\text { of N1 @ } \\
11.11 \% . \\
(1+\mathrm{g})^{\mathrm{n}}\end{array}$ & $\begin{array}{c}\text { Projected } \\
\text { Income/Rent } \\
\text { Per Annum }\end{array}$ & $\begin{array}{c}\text { Years } \\
\text { Purchase } \\
\text { (YP) 3 Years } \\
\text { @ } 15.5 \%\end{array}$ & $\begin{array}{c}\text { Present } \\
\text { Value (PV) } \\
\text { N1 @ } \\
15.5 \%\end{array}$ & Present Value \\
\hline $1-3$ & $\mathrm{~N} 3,000,000$ & 1.0000 & $\mathrm{~N} 3,000,000$ & 2.2644 & 1.0000 & $\mathrm{~N} 6,793,200$ \\
\hline $4-6$ & $\mathrm{~N} 3,000,000$ & 1.3717 & $\mathrm{~N} 4,115,100$ & 2.2644 & 0.6490 & $\mathrm{~N} 6,047,533$ \\
\hline 7 & $\mathrm{~N} 3,000,000$ & 1.8816 & $\mathrm{~N} 5,644,800$ & 2.2644 & 0.4212 & $\mathrm{~N} 5,383,814$ \\
\hline $7-$ Perpetuity & $\mathrm{N} 3,000,000$ & 2.0906 & $\mathrm{~N} 6,271,800$ & 20.0000 & 0.3647 & $\mathrm{~N} 45,746,509$ \\
\hline & & & & & & $\mathrm{N} 63,971,056$ \\
\hline
\end{tabular}

YP perpetuity @ 5\% (the growth implicit yield)

Indicated Capital Value

$\underline{\mathrm{N} 63,971,056}$

Adopted Capital Value

$\underline{\$ 64,000,000}$ 


\section{Valuation of Freehold Interest Using the Real Value/Equated Yield Hybrid Technique}

The inflation risk free yield (i) is calculated using the formula:

$$
\begin{gathered}
i=\frac{1+e-1}{1+g} \\
i=\frac{1+15.5 \%-1}{1+11.11 \%} \\
i=\frac{1+0.155-1}{1+0.1111} \\
i=\frac{1.155-1}{1.1111}
\end{gathered}
$$

$\mathrm{i}=1.0395-1$

$\mathrm{i}=0.0395$

$\mathrm{i}=0.0395 \times 100$

$\mathrm{i}=3.95 \%$

\section{Freehold Valuation}

Term

Rent received

N3,000,000 per annum

YP7 years@15.5\%

$\mathrm{x} \underline{4.0988}$

$\mathrm{N} 12,296,400$

Reversion

Current Rental Value N3,000,000 per annum

YP 3 years@ @ 15.5\% x YP perpetuity @ 3.95\%

YP 3 years@3.95\%

$2.2644 \times \underline{25.3165}$

2.7777

$2.2644 \times 9.1142=20.6382$ 
African Journal of Accounting and Financial Research

ISSN: $2682-6690$

Volume 5, Issue 1, 2022 (pp. 45-58)

www.abjournals.org

PV7years@3.95\%

x 0.7625

X 15.7366

$+\underline{\mathrm{N} 47,209,800}$

Indicated Capital Value

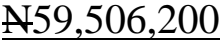

Adopted Capital Value

$\underline{\mathrm{N} 60,000,000}$

\section{Valuation of Freehold Interest Using the Rational Approach}

Term

Rental Value

N3,000,000 per annum

YP7years@15.5\%

X $\underline{4.0988}$

$\mathrm{N} 12,296,400$

Reversion

Current Rental Value

N3,000,000 per annum

Amount of $\mathrm{N} 1$ in 3 years @ 11.11\%

$\mathrm{x} \underline{1.3717}$

$\mathrm{N} 4,115,100$

YP perpetuity @ 5\%

20.0000

PV7 years@3.95\%

x 0.7625

$\underline{\mathrm{N} 62,755,275}$

Capital Value

N75,051,675

Adopted Capital Value

$\underline{\mathrm{N} 75,100,000}$ 
Table 15: Summary of Capital Values of Conventional Technique and Contemporary Technique

\begin{tabular}{|c|c|c|c|c|c|c|c|c|c|c|}
\hline \multirow{3}{*}{$\begin{array}{l}\text { Nature } \\
\text { of } \\
\text { Interest }\end{array}$} & \multicolumn{4}{|c|}{ Valuation } & \multicolumn{3}{|c|}{$\begin{array}{l}\text { Differential } \\
\mathrm{N}\end{array}$} & \multicolumn{3}{|c|}{$\%$ Difference } \\
\hline & \multirow{2}{*}{$\begin{array}{l}\text { Conven } \\
\text { tional } \\
\text { Techni } \\
\text { que } \\
\text { N000,0 } \\
00\end{array}$} & \multicolumn{3}{|c|}{$\begin{array}{l}\text { Contemporary } \\
\text { Technique } \\
\text { N }\end{array}$} & & & & & & \\
\hline & & $\begin{array}{l}\text { Disco } \\
\text { unted } \\
\text { Cash } \\
\text { Flow } \\
\text { N000 } \\
, 000 \\
\end{array}$ & $\begin{array}{l}\text { Real } \\
\text { Value } \\
\text { N000, } \\
000\end{array}$ & $\begin{array}{l}\text { Rational } \\
\text { Approac } \\
\text { h } \\
\text { N000,00 } \\
0\end{array}$ & $\begin{array}{l}\text { Discoun } \\
\text { ted } \\
\text { Cash } \\
\text { Flow } \\
\text { NoO0,0 } \\
00\end{array}$ & $\begin{array}{l}\text { Real } \\
\text { Value } \\
\text { N000,0 } \\
00\end{array}$ & $\begin{array}{l}\text { Rational } \\
\text { Approach } \\
\text { N000,00 } \\
0\end{array}$ & $\begin{array}{l}\text { Discoun } \\
\text { ted } \\
\text { Cash } \\
\text { Flow }\end{array}$ & $\begin{array}{l}\text { Real } \\
\text { Value }\end{array}$ & $\begin{array}{l}\text { Ration } \\
\text { al } \\
\text { Appro } \\
\text { ach }\end{array}$ \\
\hline $\begin{array}{l}\text { Freehold } \\
\text { Interest }\end{array}$ & $\mathrm{N} 60$ & N64 & N60 & N75.1 & $\mathrm{N} 4$ & NO & N15.1 & $6.67 \%$ & $0 \%$ & $\begin{array}{l}25.17 \\
\%\end{array}$ \\
\hline
\end{tabular}

From the information gathered from the reports of estate surveyors and valuers in respect to their past residential property investment valuations coupled with available information gathered on the rental growth, rent review period and inflation.

In the valuation of the freehold interest carried out to show the level of variation between the conventional and contemporary valuations namely, discounted cash flow, real value and rational approach, the result revealed that $6.67 \%$ variation for discounted cash flow, $0 \%$ for real value model and $25.1 \%$ rational approach compared to the conventional investment valuation. These differences arise as a result of the deficiency in the use of conventional valuation techniques in handling investment valuation problems due to lack of proper reference to rental gearing, inflation and rent reviews.

\section{SUMMARY OF FINDINGS, IMPLICATION AND CONCLUSION}

The result showed that rental values of residential properties in Lagos, comprising 2-bedroom flats and 3-bedroom flats increased at a phenomenal rate within the period, 2014-2020 while the differences in the rates of such increase within and between the various types of residential properties in the property market are not statistically significant and hence, rental growth in residential properties in the Lagos follows a similar trend and pattern. Annually (yearly) is the major lease structure used for residentials. It was confirmed that the expected rent review pattern is 3 years; practitioners are aware of the investment method, that is, the Discounted Cash. The result revealed $6.67 \%$ variation for discounted cash flow, $0 \%$ for real value model and $25.1 \%$ rational approach compared to the conventional investment valuation. These differences arise as a result of the deficiency in the use of conventional valuation techniques in handling investment valuation problems due to lack of proper reference to rental gearing, inflation and rent reviews. The use of a constant income annuity in perpetuity for conventional investment method of valuation as a single income stream would result in erroneous valuation as conventional technique relies fully on comparable evidence. The contemporary techniques on the other hand integrate property as part of the larger investment community which enables 
estate valuers to make qualitative market valuation where there is no comparable evidence. This study therefore recommends that contemporary valuation techniques are appropriate in the market valuation of residential property investments, particularly in the market valuation of reversionary freehold.

\section{REFERENCES}

Abidoye, R. \& Chan, A. (2017). Critical review of hedonic pricing model application in property price appraisal: A case of Nigeria. International Journal of Sustainable Built Environment, 6(1): 250-259.

Abidoye, R. \& Chan, A. (2017). Critical review of hedonic pricing model application in property price appraisal: A case of Nigeria. International Journal of Sustainable Built Environment, 6(1): 250-259.

Ajayi, C. A. (2019). Property investment valuation and analysis. Ibadan: De-Ayo Publishers.

Ayedun, C., Omonijo, D., Akinjare, O. \& Olorunnishola, D. (2020). Trends in the residential property rental values in Ikeja Metropolis of Lagos State, Nigeria: A comparative analysis. Vision 2025: Education Excellence and Management of Innovations through Sustainable Economic Competitive Advantage.

Bello, M. O., \& Bello, V.A. (2017). Trends in rental values of residential properties in Enugu, Nigeria: A comparative study between New Haven and Achara Layouts. Journal of Multidisciplinary Engineering Science and Technology, 3(2).

Dabara, D. \& Oyewole, M. (2015). The trends in commercial property values in an emerging real estate market: The case of Ibadan Metropolis, Nigeria. AFRES Conference.

Dugeri, T. (2019). Internalisation of valuation standards: Relevance and applicability issues in the Nigerian. Lagos, Nigeria: AFRES Publication.

Iroham, C.O., Oluwunmi, A.O, Simon, R.F. \& Akerele, B.A. (2017). Assessing the trend in rental values of commercial properties along Oyemekun Road, Akure, Nigeria. Covenant Journal of Research in the Built Environment, 1(1): 10-29.

Sykes, N. (2019). The Application of equated yield and real value approaches to the market valuation of commercial property investments. London, United Kingdom: University of Reading Publication.

Udo, G. (2018). Property valuation: The optimization of the market approach by a weighted appraisal model. Journal of Property Investment \& Finance, 38 (5): 399-418. 